Araştırma Makalesi - ResearchArticle

\title{
Geosentetik Donatılı İstinat Duvarının Analitik, Deneysel ve Sonlu Elemanlar Yöntemleri ile Performans Analizi
}

\author{
Eren Balaban ${ }^{1 *}$, Aleš Šmejda ${ }^{2}$, Mehmet İnanç Onur ${ }^{3}$
}

Kabul / Accepted: 01/10/2020

\section{$\overline{\text { ÖZ }}$}

İnşa edilmelerinin kolaylığı ve deprem yükleri altında sergiledikleri performanstan dolayı donatılı zemin uygulaması ile inşa edilen istinat duvarlarına olan ilgi dünya çapında artmaktadır. Bu çalışmada $450 \mathrm{~mm}$ yüksekliğinde kum ve kil dolguya sahip donatıı istinat duvarları inşa edilerek köprü ayağı yükleme şartlarında test edilmiştir. Elde edilen test sonuçlarından yararlanılarak sonlu elemanlar modeli oluşturulmuştur. Sonlu elemanlar ile yapılan parametrik çalışmada donatı rijitliği, donatı sıklığı ve donatı uzunluğunun temel oturmasına, istinat duvarı boyunca oluşan yatay deplasmanlara, her bir donatı üzerinde oluşan maksimum çekme kuvveti ile toplam maksimum çekme kuvvetine ve şev duyarlılığı üzerindeki etkileri araştırılmıştır.

\footnotetext{
${ }_{1 *}^{*}$ Sorumlu yazar iletişim: erenb@eskisehir.edu.tr (https://orcid.org/0000-0001-9559-0127) Department of Civil Engineering, Eskisehir Technical University, IkiEylul Campus, Eskisehir, Turkey 2İletişim: ales.smejda@upce.cz (https://orcid.org/0000-0003-1457-0285)

Department of Transport Structures, University of Pardubice, Jan Perner Transport Faculty, Czech Republic 3̇letişim: mionur@eskisehir.edu.tr (https://orcid.org/0000-0002-2421-4471)

Department of Civil Engineering, Eskisehir Technical University, IkiEylul Campus, Eskisehir, Turkey
} 


\title{
Performance Analysis of Geosynthetic Reinforced Earth Wall by Analytical Experimental and Finite Element Methods
}

\begin{abstract}
Ease of construction and performance under earthquake loads causes interest in construction of reinforced earth walls worldwide. In this study, reinforced earth walls with sand and clay backfill at a height of $450 \mathrm{~mm}$ are constructed and tested under bridge abutment loading conditions. A finite element analysis is performed and results are compared with experiment results. In the parametric study made by conducting finite element method, effect of reinforcement stiffness and reinforcement density on the horizontal displacements along the retaining wall face, the maximum tensile force, total maximum tensile force, and slope stability are investigated.
\end{abstract}




\section{INTRODUCTION}

Reinforced earth walls have been constructed all over the world since they are light weight and easy to construct. They are also less susceptible to eartquake forces. Due to those advantageous properties, reinforced earth walls have been preferred frequently. There are several design codes around the world related to design parameters of reinforced earth walls. These design codes limit the properties of soil to be used for construction of reinforced earth wall. However, there are lots of examples in the literature that cohesive or marginal soils have been used in the construction of reinforced earth wall [1-8]. It is said that when cohesive soil is used during construction, higher strains acting on reinforcement is measured [1,8]. It is also stated in [8] that in the case of clay backfill creep forces are higher. Therefore, increase in creep forces yields increase in wall displacement [5]. However, in [6], it is stated that increase in cohesion yields lower wall displacements. In a hybrid backfilled reinforced earth wall in which top half of the backfill is clay and remaining is sand, two peak stresses acting over reinforcements are observed [4]. In a study regarding failure of reinforced earth wall [7], one of the main reason is stated as the fine particles reduces permeability which caused failure after heavy rain. There is also study to improve behaviour of fine backfill by treating with lime [3]. There are also studies regarding performance of reinforced earthwalls considering effects of various factors [9-18]. Behaviour of reinforced earth wall under strip loading is studied experimentally [9]. Experimental and numerical studies are conducted for two tiered walls [10]. Study revealed that maximum horizontal tensile loads on lower part decrease as the upper part move away from lower part. However, after some distance, maximum tensile force on reinforcements remains constant. Using demolition waste as a backfill is investigated by [11] for a reinforced earth wall over collapsible soil. Performance of geosynthetically reinforced earth wall under static footing load over rigid foundation is studied by [12]. Effect of connection type, width of foundation, length of foundation, and offset distance of footing is investigated. Effect of compaction into reinforcement strains are investigated by [13]. It is seen that well compacted soil yielded higher strains on reinforcements but lower horizontal displacement of wall facing. Polypropylene fibers are added into backfill soil, and its performance is evaluated by [14]. Time dependent behavior of reinforced earth wall is studed using centrifuge setup by [15]. Short term and long term performance of reinforced earth wall is determined in this study. Geogrid and sand-fly ash backfill is used as reinforcement for counterfort retaining wall [16]. Addition of those materials yielded more stable counterfort wall. Experiments and finite element models are conducted by [17] to clarify the bearing capacity of strip footing on reinforced earth wall. Effect of number of reinforcement, depth of reinforcement, vertical spacing of reinforcement and distance of footing are considered during study. Effect of recycled tire chips mixed with sand is studied by [18].

It is very clear that effects of various conditions on the performance of reinforced earth walls are studied in the literature. Although performance of reinforced earth wall is evaluated both for sand and clay soils, there is lack of study in order to compare the behaviour of earth walls constructed with sand and clay backfills under effect of footing load. Therefore, model walls are constructed in the laboratory with sand and clay backfills and tested. Parametric study is conducted considering effect of reinforcement stiffness, reinforcement density, and reinforcement length to settlement of footing, horizontal displacement, maximum horizontal tensile force, and total horizontal tensile force and slope stability. Tensile forces acting over each reinforcement layers are calculated analytically according to federal highway administration (FHWA) method. Calculated forces are compared with computed forces by finite element models.

\section{MATERIAL AND METHOD}

Crushed sand and locally available clay are used in this study. Material properties are determined at laboratory except specific gravity of sand. Specific gravity of sand is given as 2.9 by the producer. Sieve analysis is conducted at laboratory for classification of sand. Particle size distribution of sand is given on Figure 1 below. According to result of particle size distribution coefficient of uniformity $\left(\mathrm{C}_{\mathrm{u}}\right)$ and coefficient of gradation $\left(\mathrm{C}_{c}\right)$ is calculated as 3.3 and 0.84 respectively. According to $\mathrm{C}_{\mathrm{u}}$ and $\mathrm{C}_{\mathrm{c}}$, sand is classified as poorly graded sand (SP) according to unified classification system.

Particle size distribution of clay sample is given on Figure 2. Liquid limit and plastic limit of the clay sample is determined as 35.9 and 20.2 respectively. Clay is classified as CL according to unified classification system. 


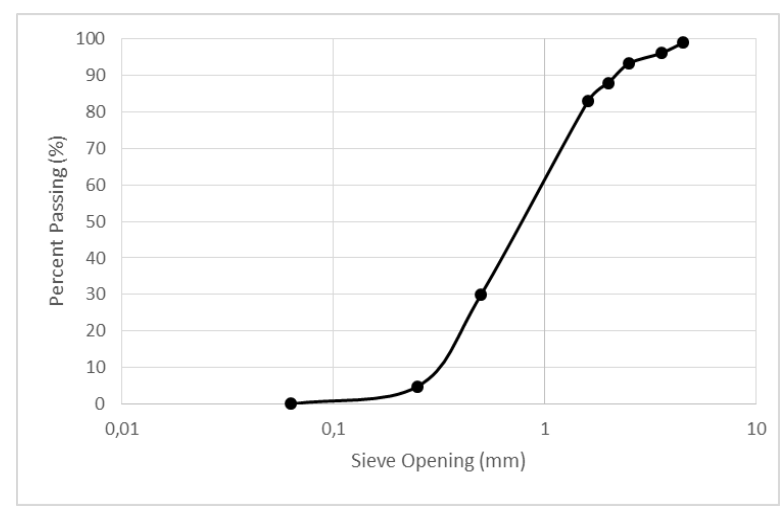

Figure1. Particle size distribution of sand

Standard proctor test is conducted in order to determine maximum dry unit weight and optimum water content for both samples. Maximum dry unit weights are found as $17.4 \mathrm{kN} / \mathrm{m}^{3}$ and $18.5 \mathrm{kN} / \mathrm{m}^{3}$, optimum water contents are found as $11.5 \%$ and $12.5 \%$ for sand and clay samples respectively.

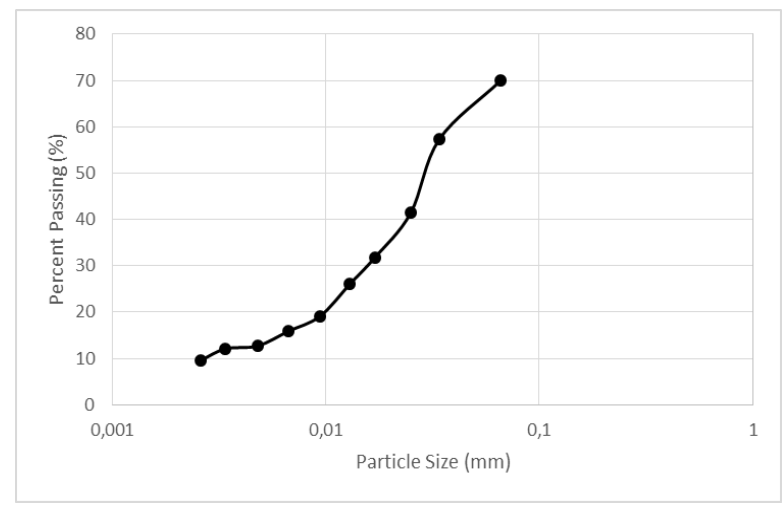

Figure 2. Particle size distribution of clay

Direct shear tests are conducted to sand and clay samples in order to determine angle of friction and cohesion. Direct shear tests are conducted according to Czech Standart CSN CEN ISO/17892-10. Speed of direct shear test differs for sand and clay according to standart. Applied shear rate equals to $0.25 \mathrm{~mm} / \mathrm{min}$ to sand samples while it is equal to $0.0625 \mathrm{~mm} / \mathrm{min}$ for clay samples in order to prevent development of excess pore water pressure. Angle of frictions are found as $47.4^{\circ}$ and $32.4^{\circ}$ for sand and clay respectively. Cohesion values are found as $0.5 \mathrm{kPa}$ and $38.7 \mathrm{kPa}$ for sand and clay.

Wrap - around reinforced walls are constructed at a height of $450 \mathrm{~mm}$ with 9 layers of geotextile. Geotextile layers are equally distributed at an interval of $50 \mathrm{~mm}$. Both sand and clay is compacted at their optimum water contents. Commercially available geotextile is used throughout the study. Tensile strenght of geotextile is provided as $110 \mathrm{kN} / \mathrm{m}$ and $50 \mathrm{kN} / \mathrm{m}$ longitudinally and laterally respectively. Tensile strengths are achieved at $10.5 \%$ and $11 \%$ strains longitunally and laterally respectively.Stiffness of geotextile is calculated as $1048 \mathrm{kN} / \mathrm{m}$. Static loading is applied as consecutive loading sequences. Initial load is selected such that it corresponds to $0.06 \mathrm{MPa}$ vertical stress. It is increased in each new load step by $0.06 \mathrm{MPa}$. Horizontal displacements of wall face are measured at three different locations. Settlement of loading plate is also measured. Experimental setup is provided at Figure 3. 


\begin{tabular}{|c|c|c|}
\hline & $\begin{array}{l}\text { BŞEÜ Fen Bilimleri Dergisi } \\
7(2), 621-637,2020\end{array}$ & $\begin{array}{r}\text { BSEU Journal of Science } \\
\text { DOI: } 10.35193 / \text { bseufbd. } 705157\end{array}$ \\
\hline $\begin{array}{l}\text { BilEECISSEYHEDEBALI } \\
\text { UNIVERSITESI }\end{array}$ & & 88-7575 (http://dergipark.gov.tr/bseufbd) \\
\hline
\end{tabular}

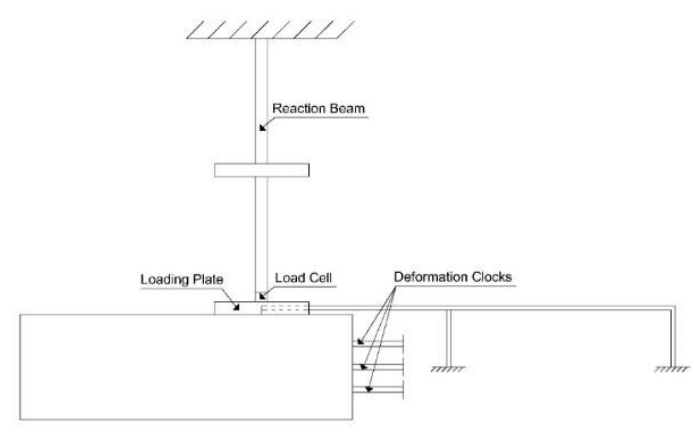

Figure 3. Experiment setup of laboratory test

Experiment cell is constructed at the laboratory especially to perform these kind of tests. It is made of steel and covered by thick plexi-glass. Middle section of the plexi-glass cover is strengthen by steel bars to prevent from unintended deformation. Experiment cell is approximately $3.5 \mathrm{~m} * 1.5 \mathrm{~m} * 2 \mathrm{~m}$ by length, width and height respectively. Loading plate is chosen identical to static loading plate whose diameter equal to 266 $\mathrm{mm}$. Dimension of the loading plate is chosen such that it represent the loading conditions of a bridge abutment constructed on reinforced earth walls. Loading cell may be seen on Figure 4 below.

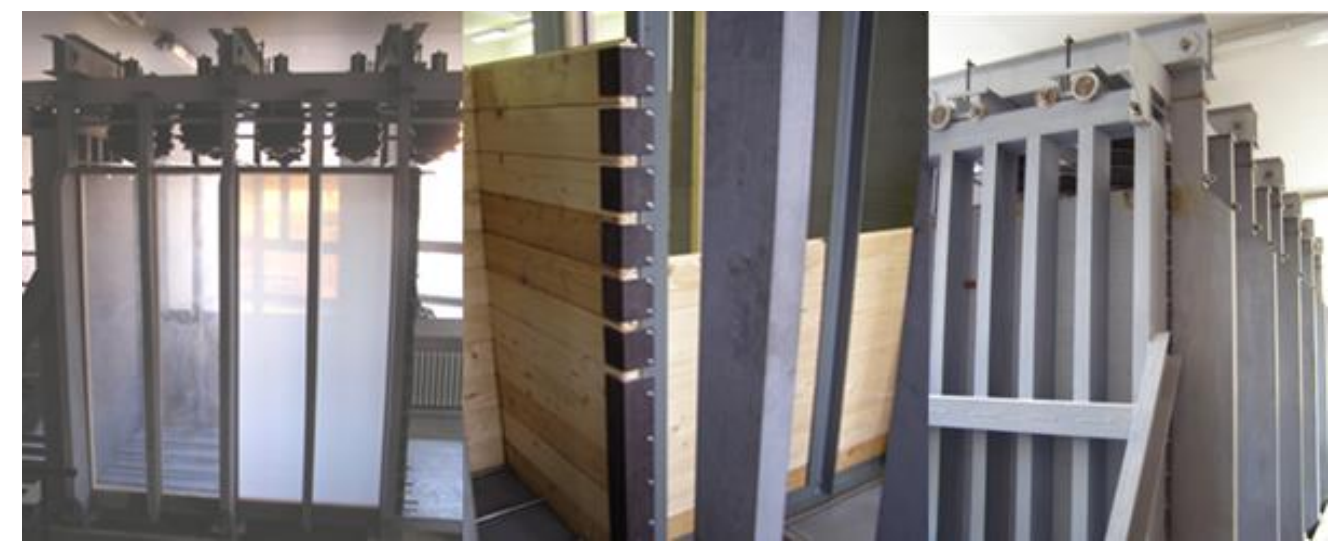

Figure 4. Loading cell used during study

Walls are constructed by compacting sand and clay by layer by layer. All walls are constructed in 9 lifts which each lift equals to $50 \mathrm{~mm}$. Required amount of soil is prepared for each lift and then placed over reinforcement. After that, compaction is applied by using hand plate. 95\% relative density of maximum dry unit weight determined by standard proctor test is achieved for each lift.

Plaxis finite element code is used in order to simulate experiments, 15 nodes and 12 stress points are used during meshing of structures.Plaxis model was created as same as the test model. Plaxis model has height of $500 \mathrm{~mm}$ and width of $650 \mathrm{~mm}$. Geotextile layers are placed in finite element model same as experiment which means there is $50 \mathrm{~mm}$ interval between two consecutive layers. Finite element models consist of 1519 elements, 12371 nodes, 18228 stress points. Average element size is given as $15.18 \mathrm{~mm}$.Meshed structure from finite element code is given on Figure 5 below. Mohr - Coulomb material model is applied to sand and clay while elastic material is assigned to plate element representing loading plate. Plastic analysis with updated mesh condition is performed during study. Loading stage is simulated by applying point load to center of loading plate which is identical to tests performed. In order to determine factor of safety against slope stability, stress reduction method is applied. This method reduces strength parameters of soils until the slope failure occurs, and 
then calculates the ratio between initial value and final reduced value which is the factor of safety against slope failure. This analysis can be performed by selecting phi-c reduction method in Plaxis. This method was applied in this study in order to calculate factor of safety against slope stability.Material properties of soils are determined by using results of direct shear tests. Loading plate is modelled as rigid material. Material properties of soils and rigid plate are provided on Table 1.

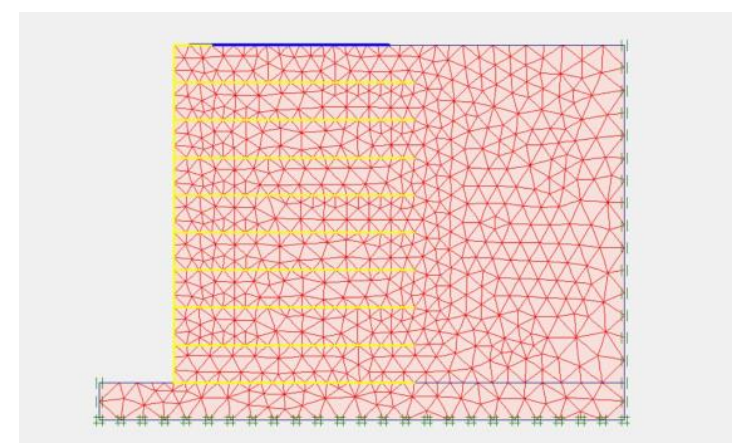

Figure 5. Meshed structure of finite element model

Table 1. Material Properties used in finite element models

\begin{tabular}{lccc}
\hline & \multicolumn{3}{c}{ Materials } \\
\cline { 2 - 4 } & Sand & Clay & Loading Plate \\
\hline Unit Weight $\left(\mathrm{kN} / \mathrm{m}^{3}\right)$ & 17.4 & 18.5 \\
Elasticity Modulus $(\mathrm{kPa})$ & 64020 & 85670 & \\
Poisson's Ratio & 0.3 & 0.3 & \\
Angle of Friction $\left({ }^{\circ}\right)$ & 47.4 & 32.4 & $10^{9}$ \\
Cohesion $(\mathrm{kPa})$ & 1.0 & 37.7 & $10^{8}$ \\
Dilatency Angle $\left({ }^{\circ}\right)$ & 17.4 & 2.4 & \\
Axial Stiffness $(\mathrm{EA})(\mathrm{kN} / \mathrm{m})$ & - & - & \\
Bending Stiffness $(\mathrm{EI})$ & - & - & \\
\hline
\end{tabular}

Elasticity modulus of sand and clay backfills are calculated from shear modulus determined from direct shear tests results conducted at $100 \mathrm{kPa}$. Shear modulus of samples are determined by dividing shear stress corresponding to $0.2 \%$ strain. As poisson's ratio is chosen as 0.3 which is very common for soil samples, elasticity modulus is calculated by following formula.

$$
\mathrm{E}=2 \mathrm{G}(1+v)
$$

Poisson's ratio is determined according to literature as 0.3 which is the smallest value for the dense sand. Same value is accepted for clay and it is in the given interval by [22]. Dilatency angle is computed by the following formula which is commonly accepted in literature.

$$
\psi=\phi-30
$$

FHWA design method is a load resistance factor design method. This means that loads acting on structures are increased by a factor while resistance of a structure is decreased. This design methodology is applied in our study in order to determine loads and resistance of structure. Details of the design method can be found on [23]. 


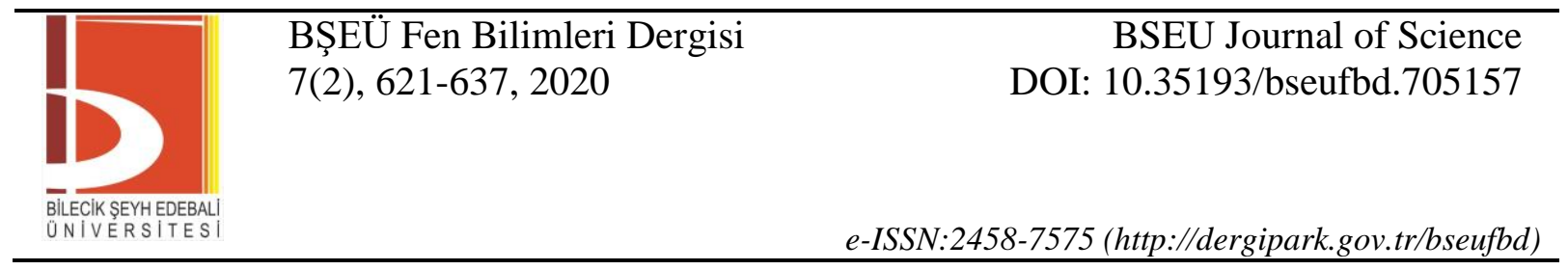

\section{RESULTS}

\section{A. Experiment Results}

Static tests are continued until walls are failed. The failure occured at different load states. When sand backfill is used during construction, wall withstood against $0.50 \mathrm{MPa}$ footing stress, however, in case of clay backfill, reinforced earth wall was only able to withstand against $0.18 \mathrm{MPa}$ footing stress. Settlement of loading plate is lower for sand backfill than clay backfill. Settlement measured for sand backfill equals to $4.44 \mathrm{~mm}$ under $0.5 \mathrm{MPa}$. When clay backfill is considered, settlement of loading plate is measured as $1.62 \mathrm{~mm}$ under $0.19 \mathrm{MPa}$. Measured settlement values for sand and clay is given on Figure 6.

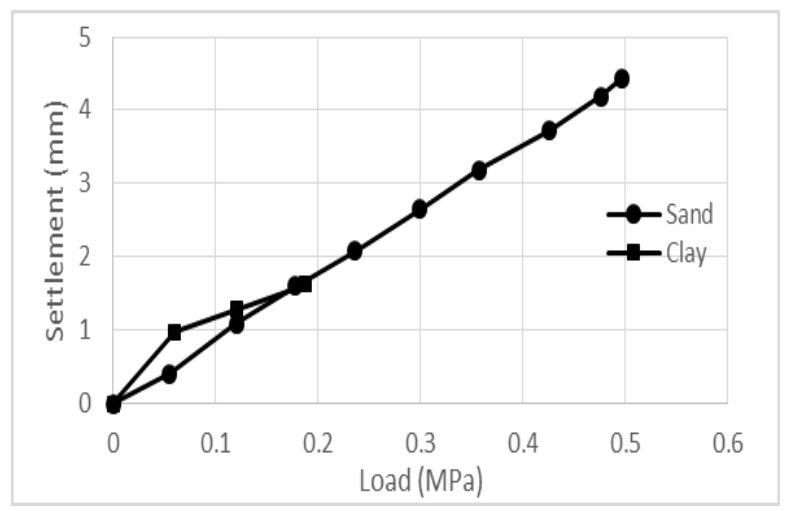

Figure 6. Settlement of loading plates

Although the difference between settlement values seems to be low, loading is stopped for clay backfilled sample, because wall failed. Failure of wall is observed when loading is tried to be increased, settlements increased and loads stayed constant. Failure cracks are also observed. Those failure cracks may be seen on Figure 7.

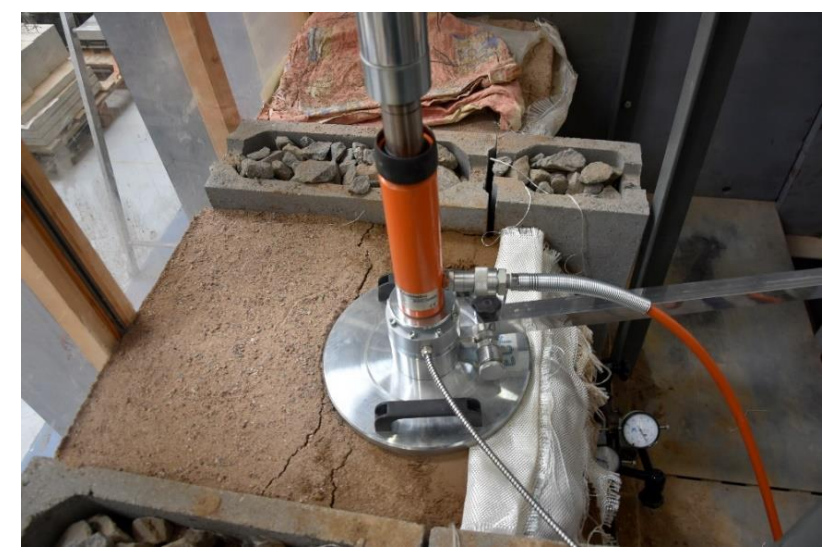

Figure 7. Failure cracks of reinforced earth wall with clay backfill

Horizontal displacements are measured for sand backfill under $0.5 \mathrm{MPa}$ is found to be $1.9 \mathrm{~mm}, 1.4 \mathrm{~mm}$ and $0.67 \mathrm{~mm}$ at top, middle and bottom of the wall respectively. Horizontal displacements increase to $3.4 \mathrm{~mm}$, $4.9 \mathrm{~mm}$ and $2.6 \mathrm{~mm}$ at top, bottom and middle of the wall respectively under 0.19 MPa for clay backfill. Results show that although lower load is applied to clay backfill, horizontal displacements are higher than sand backfill. 


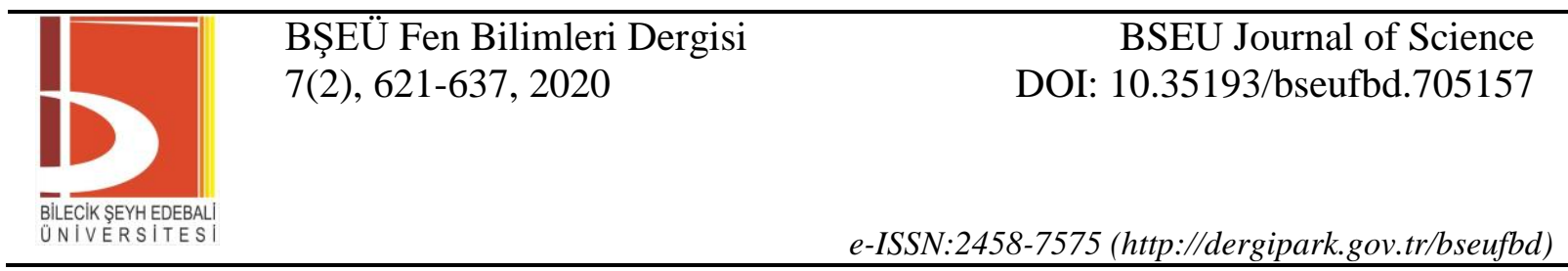

Measured horizontal displacements for clay backfill show that bulging occured at the middle of the wall. Change of horizontal displacements with respect to magnitude of load and backfill type is shown on Figure 8 .

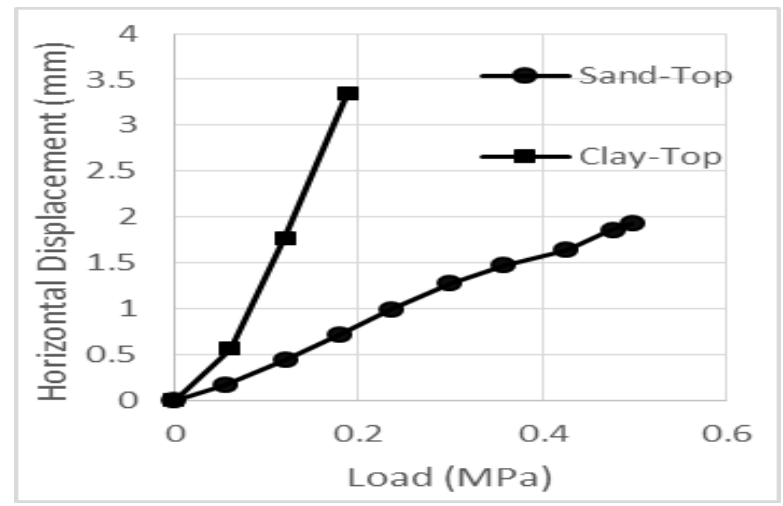

(a)

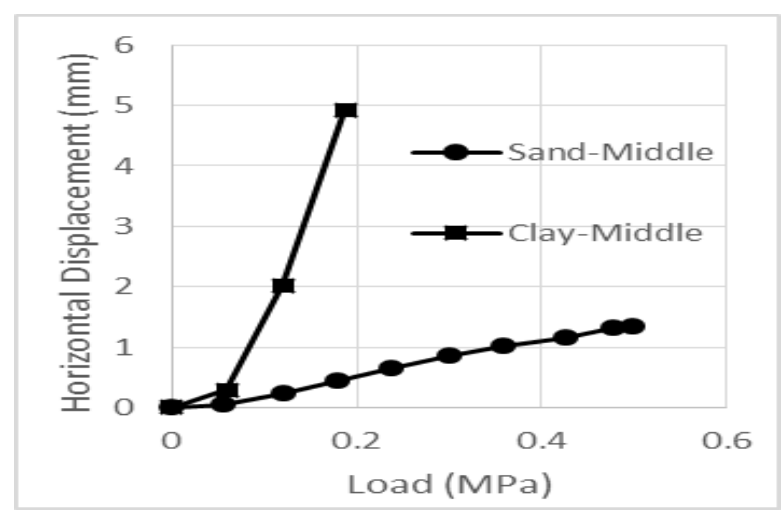

(b)

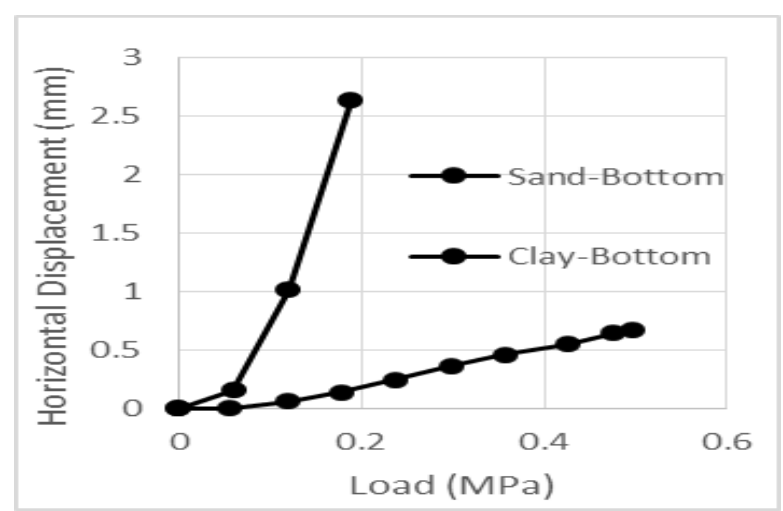

(c)

Figure 8. Horizontal displacements measured for sand and clay backfills (a) top (b) middle (c) bottom of wall

\section{B. Finite Element Models}

The results of laboratory tests are compared initially in order to show finite element model is capable for parametric study. Results of parametric study are presented later in this section for both type of backfills. Finite element analysis performed under same loading conditions and same load magnitudes as experimental study performed at the laboratory. This means that loading of walls were stopped when applied vertical stress 
was equal to $0.5 \mathrm{MPa}$ for sand backfill, while it is stopped when applied vertical stress was equal to $0.19 \mathrm{MPa}$ for clay backfill. Those stress levels were maintained throughout the study with respect to backfill type. Settlement of loading plate for sand backfill is computed as $3.6 \mathrm{~mm}$ while it is measured as $4.4 \mathrm{~mm}$ under 0.5 MPa load. Horizontal deformation profiles computed by Plaxis software is given on Figure 9 and Figure 10 for sand and clay backfill respectively.

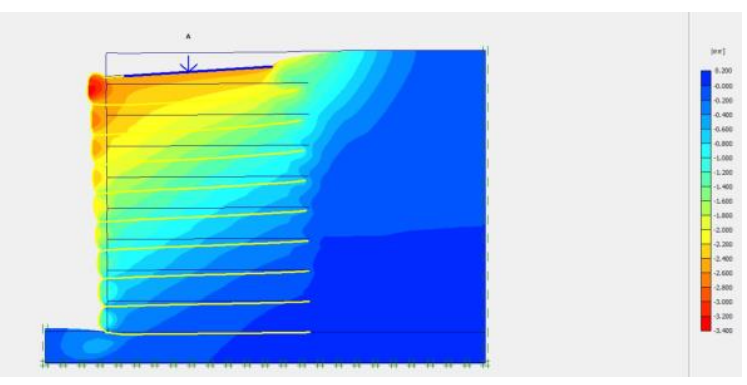

Figure 9. Horizontal deformation profile for sand backfill at $0.50 \mathrm{MPa}$

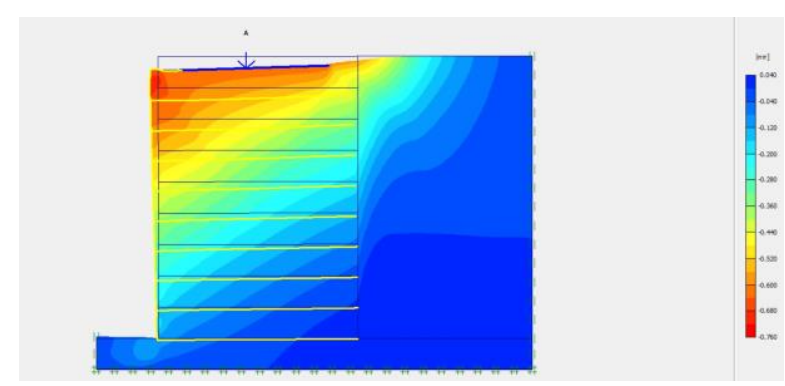

Figure 10. Horizontal deformation profile for clay backfill at $0.19 \mathrm{MPa}$

Increment of settlements under different load levels are provided on Figure 11. It is seen from Figure 11 that results for settlement complies with each other. It should be noted that settlements better comply with each other at lower load levels, while deviations begin at higher load levels.

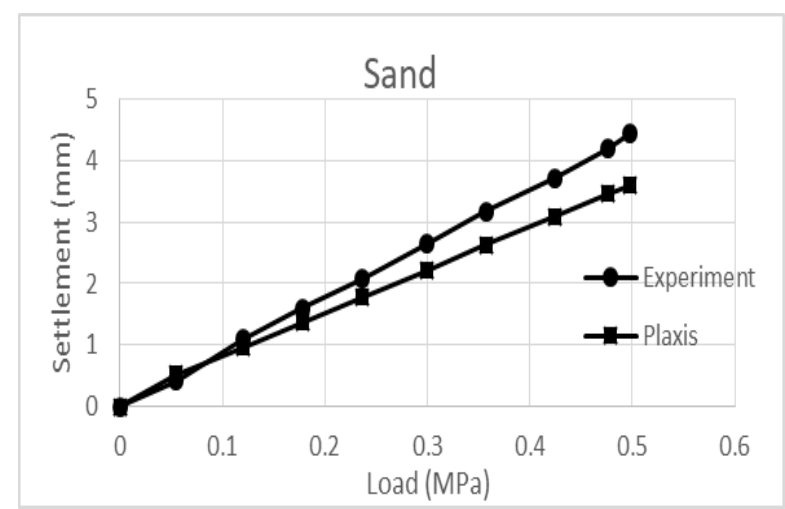

Figure 11. Measured and computed settlements of loading plate under various loads for sand backfill

When settlement of loading plate is compared for clay backfill, it is seen that lower settlements are computed by finite element. Settlement is computed as $0.99 \mathrm{~mm}$ under $0.19 \mathrm{MPa}$ while it is measured as 1.62 


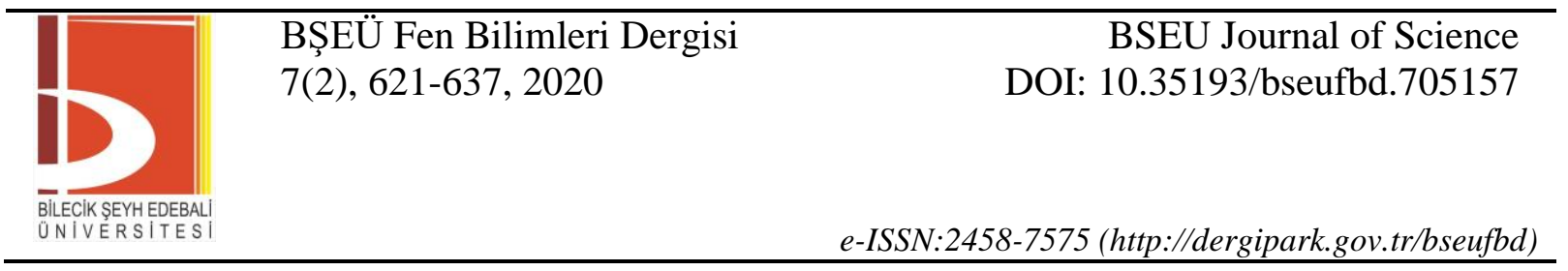

mm during experiment. Comparison of settlements for other load levels may be seen on Figure 12 given below. Plaxis overestimated horizontal displacements for sand backfill and underestimated for clay backfill.

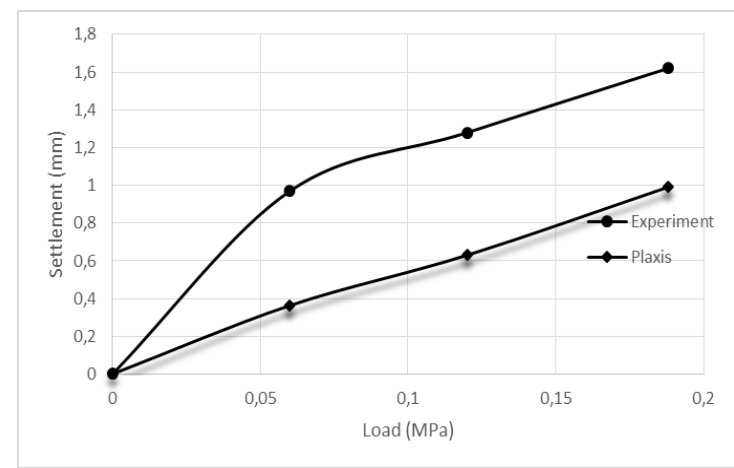

Figure 12. Measured and computed settlements of loading plate under various loads for clay backfill

The highest horizontal displacements are computed as $2.54 \mathrm{~mm}, 2.06 \mathrm{~mm}$ and $1.15 \mathrm{~mm}$ at top, middle, and bottom of the wall respectively for sand under $0.5 \mathrm{MPa}$. In case of clay backfill, computed horizontal displacements decreases to $0.72 \mathrm{~mm}, 0.42 \mathrm{~mm}$ and $0.23 \mathrm{~mm}$ at top, middle and bottom of the wall respectively under 0.19 MPa. Horizontal displacements under various displacements are given on Table 2 and Table 3 for sand and clay backfills respectively.

Table 2. Measured and computed horizontal displacement of horizontal displacement for sand backfill

\begin{tabular}{lcclccc}
\hline $\begin{array}{c}\text { Load } \\
(\mathbf{M P a})\end{array}$ & \multicolumn{7}{c}{ Top } & MiddleBottom & & & \\
\cline { 2 - 7 } & $\begin{array}{c}\text { Experiment } \\
(\mathbf{m m})\end{array}$ & $\begin{array}{l}\text { Plaxis } \\
(\mathbf{m m})\end{array}$ & $\begin{array}{l}\text { Experiment } \\
(\mathbf{m m})\end{array}$ & $\begin{array}{l}\text { Plaxis } \\
(\mathbf{m m})\end{array}$ & $\begin{array}{l}\text { Experiment } \\
(\mathbf{m m})\end{array}$ & $\begin{array}{l}\text { Plaxis } \\
(\mathbf{m m})\end{array}$ \\
\hline 0 & 0 & 0 & 0 & 0 & 0 & 0 \\
0.06 & 0.17 & 0.38 & 0.05 & 0.28 & 0 & 0.19 \\
0.12 & 0.44 & 0.66 & 0.24 & 0.52 & 0.06 & 0.28 \\
0.18 & 0.72 & 0.94 & 0.45 & 0.76 & 0.14 & 0.43 \\
0.24 & 1.00 & 1.23 & 0.65 & 0.98 & 0.24 & 0.55 \\
0.30 & 1.28 & 1.54 & 0.86 & 1.24 & 0.36 & 0.69 \\
0.36 & 1.48 & 1.84 & 1.02 & 1.48 & 0.46 & 0.83 \\
0.43 & 1.65 & 2.18 & 1.16 & 1.77 & 0.55 & 0.99 \\
0.48 & 1.86 & 2.44 & 1.32 & 1.97 & 0.64 & 1.10 \\
0.50 & 1.93 & 2.54 & 1.35 & 2.06 & 0.70 & 1.15 \\
\hline
\end{tabular}

Table 3. Measured and computed horizontal displacement of horizontal displacement for clay backfill

\begin{tabular}{lcccccc}
\hline $\begin{array}{c}\text { Load } \\
(\mathbf{M P a})\end{array}$ & \multicolumn{2}{c}{ Top } & \multicolumn{2}{c}{ Middle } & \multicolumn{2}{c}{ Bottom } \\
\cline { 2 - 7 } & $\begin{array}{c}\text { Experiment } \\
(\mathbf{m m})\end{array}$ & $\begin{array}{l}\text { Plaxis } \\
(\mathbf{m m})\end{array}$ & $\begin{array}{l}\text { Experiment } \\
(\mathbf{m m})\end{array}$ & $\begin{array}{l}\text { Plaxis } \\
(\mathbf{m m})\end{array}$ & $\begin{array}{l}\text { Experiment } \\
(\mathbf{m m})\end{array}$ & $\begin{array}{l}\text { Plaxis } \\
(\mathbf{m m})\end{array}$ \\
\hline 0 & 0 & 0 & 0 & 0 & 0 & 0 \\
0.06 & 0.57 & 0.27 & 0.29 & 0.15 & 0.16 & 0.08 \\
0.12 & 1.78 & 0.43 & 2.20 & 0.25 & 1.02 & 0.13 \\
0.19 & 3.35 & 0.72 & 4.93 & 0.42 & 2.64 & 0.23 \\
\hline
\end{tabular}

Since measured and computed values are close enough, especially for sand backfill, parametric study may be conducted. 


\section{Parametric Study}

Results of parametric study considering geotextile stiffness and reinforcement density are presented in this section. Factor of safety against slope stability with respect to load level is provided in this section also. In case of tensile loads on geotextile are also calculated according to federal highway administration method (FHWA) and compared with finite element method results.

1) Effect of Geotextile Stiffness: In order to determine the effect of geotextile stiffness, additional stiffness values of $2096 \mathrm{kN} / \mathrm{m}, 4000 \mathrm{kN} / \mathrm{m}, 8000 \mathrm{kN} / \mathrm{m}$ and $10000 \mathrm{kN} / \mathrm{m}$ are used. Calculated results are compared with each other. When tensile loads acting on reinforcements are compared, it is seen that higher maximum tensile loads are observed at higher reinforcement stiffness. However, FHWA method underpredicts the tensile loads on the reinforcements for both backfill type. Reinforcement tensile loads are provided on Table 4 for sand backfill and Table 5 for clay backfill. Negative tensile forces are computed according to FHWA when clay backfill is considered, however positive values are computed in each different reinforcement density for clay backfill.

Table 4. Computed maximum tensile forces with respect to stiffnesses for sand backfill

\begin{tabular}{lcccccc}
\hline \multirow{2}{*}{$\begin{array}{c}\text { Layer } \\
\text { Number }\end{array}$} & \multicolumn{7}{c}{ Stiffness } \\
\cline { 2 - 7 } & $\mathbf{1 0 4 8} \mathbf{~ k N / m}$ & $\mathbf{2 0 9 6} \mathbf{~ k N / m}$ & $\mathbf{4 0 0 0} \mathbf{~ k N / m}$ & $\mathbf{8 0 0 0} \mathbf{~ k N / m}$ & $\mathbf{1 0 0 0 0} \mathbf{~ k N / m}$ & FHWA \\
\hline 1 & 4.58 & 4.91 & 5.89 & 7.23 & 7.65 & 6.21 \\
2 & 4.86 & 5.08 & 6.69 & 8.77 & 9.39 & 3.76 \\
3 & 4.70 & 5.22 & 6.72 & 8.70 & 9.26 & 3.51 \\
4 & 4.66 & 5.37 & 6.57 & 8.26 & 8.75 & 3.38 \\
5 & 4.96 & 5.60 & 6.80 & 8.30 & 8.77 & 3.18 \\
6 & 5.10 & 5.72 & 6.94 & 8.41 & 8.88 & 2.93 \\
7 & 5.19 & 5.83 & 7.03 & 8.39 & 8.84 & 2.79 \\
8 & 5.08 & 5.79 & 6.94 & 8.09 & 8.48 & 2.66 \\
9 & 3.28 & 3.91 & 4.96 & 6.20 & 6.62 & 1.28 \\
\hline
\end{tabular}

Table 5. Computed maximum tensile forces with respect to stiffnesses for clay backfill

\begin{tabular}{lcccccc}
\hline \multirow{2}{*}{$\begin{array}{c}\text { Layer } \\
\text { Number }\end{array}$} & \multicolumn{7}{c}{ Stiffness } \\
\cline { 2 - 7 } & $\mathbf{1 0 4 8} \mathbf{~ k N / m}$ & $\mathbf{2 0 9 6} \mathbf{~ k N / m}$ & $\mathbf{4 0 0 0} \mathbf{~ k N / m}$ & $\mathbf{8 0 0 0} \mathbf{~ k N / m}$ & $\mathbf{1 0 0 0 0} \mathbf{~ k N / m}$ & FHWA \\
\hline 1 & 1.75 & 1.82 & 2.32 & 2.85 & 3.02 & 0.49 \\
2 & 1.36 & 1.64 & 2.21 & 2.93 & 3.17 & 0.05 \\
3 & 1.24 & 1.66 & 2.18 & 2.83 & 3.05 & -0.13 \\
4 & 1.32 & 1.75 & 2.27 & 2.78 & 2.97 & -0.29 \\
5 & 1.40 & 1.78 & 2.28 & 2.78 & 2.93 & -0.42 \\
6 & 1.49 & 1.83 & 2.34 & 2.84 & 2.99 & -0.54 \\
7 & 1.56 & 1.88 & 2.40 & 2.89 & 3.04 & -0.65 \\
8 & 1.51 & 1.91 & 2.38 & 2.84 & 2.97 & -0.74 \\
9 & 0.73 & 1.07 & 1.49 & 1.98 & 2.14 & -0.40 \\
\hline
\end{tabular}

Horizontal displacements tend to decrease as the reinforcement stiffness increases. However, amount of change in computed horizontal displacement gets lower in higher reinforcement stiffnesses. Change of horizontal dipslacements for sand backfill is given on Figure 13. 


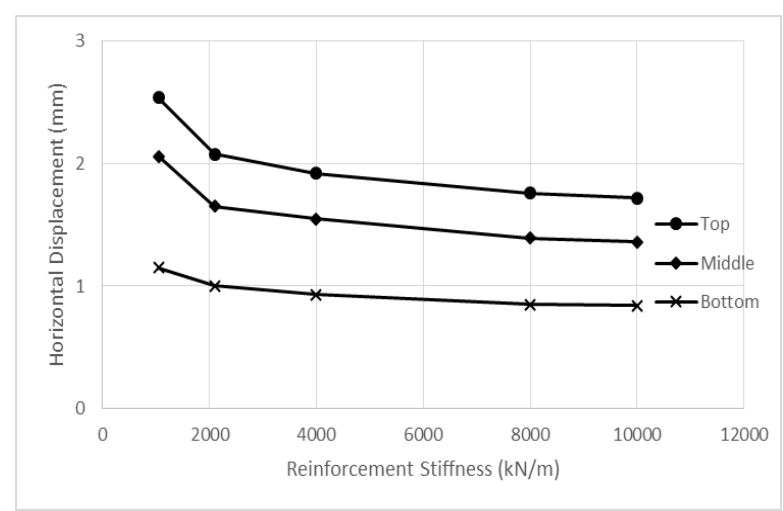

Figure 13. Horizontal displacements for reinforcement stiffness for sand backfill

The initial decrease of the horizontal displacements while the reinforcement stiffness increases is steeper in case of clay backfill than sand backfill at the top of the wall. In case of displacements at the middle of the wall, the change becomes less steep and at the bottom, it becomes straight line. Figure 14 shows the change of horizontal displacements for clay backfill with various reinforcement stiffness.

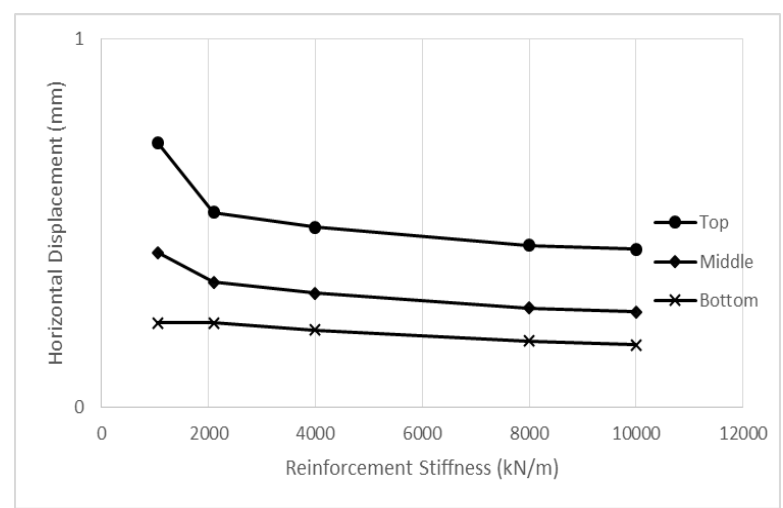

Figure 14. Horizontal displacements for reinforcement stiffness for clay backfill

Settlement of loading plate is affected by the reinforcement stiffness in case of sand backfill. Settlement of loading plate is lower while the reinforcement stiffness is higher. However, decrement of settlement gets lower as the reinforcement stiffness gets higher. Effect of reinforcement stiffness to loading plate settlement is almost disappeared in case of clay backfill. Change of settlements with respect to reinforcement stiffness is given on Figure 15. 


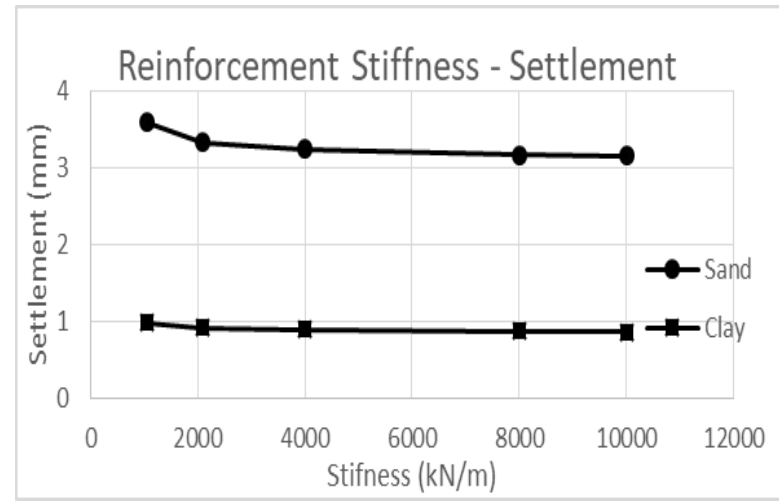

Figure 15. Settlement of loading plate with respect to reinforcement stiffness

2) Effect of Reinforcement Density: Reinforcement density can be changed by changing the distance between two consecutive layers. If the distance between two consecutive layers is the highest, then the reinforcement density will be the lowest. Three different density levels are considered in this study as high reinforcement density, medium reinforcement density, and low reinforcement density. The distance between reinforcement layers are chosen as $30 \mathrm{~mm}, 50 \mathrm{~mm}$ and $90 \mathrm{~mm}$ respectively. High reinforcement density can be seen on Figure 16 while less dense reinforcement density can be seen on Figure 17. It is seen that as the density of reinforcement increases, settlement of loading plate decreases. Computed settlements may be given as 3.1 $\mathrm{mm}, 3.6 \mathrm{~mm}$ and $5.34 \mathrm{~mm}$ from high reinforcement density to low reinforcement density respectively.

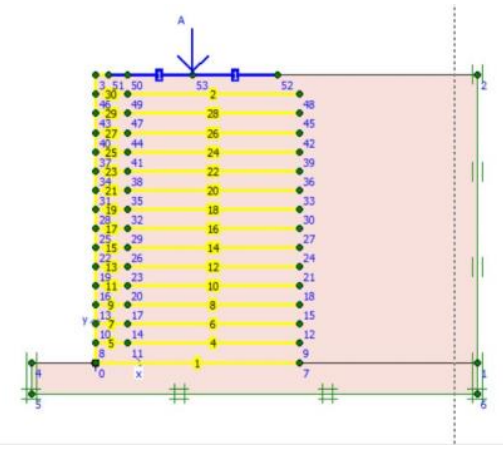

Figure 16. High reinforcement density configuration in FEM analysis

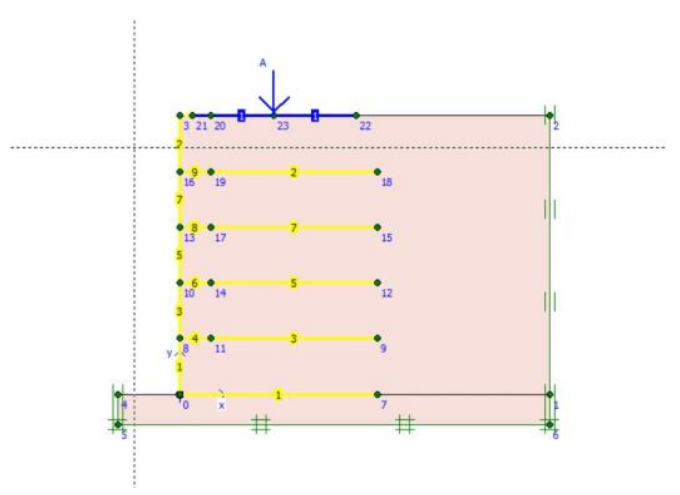

Figure 17. Less reinforcement density configuration in FEM analysis 


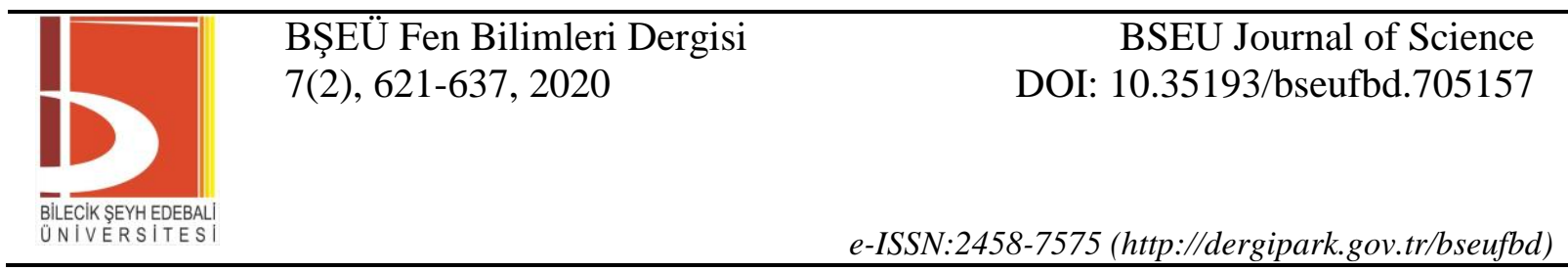

When the horizontal displacements are considered with respect to reinforcement density, it is seen that there is a slight difference between high and medium reinforcement densities. However, horizontal displacements increase enourmously if the low reinforcement density is applied during the design. It should be noted that almost same deformations are calculated especially at the lower part of walls for high reinforcement density and medium reinforcement density. Figure 18 shows the displacement profile of reinforced earth wall. When maximum tensile force acting over reinforcement layers, it is seen that tensile forces decreases as reinforcement density increases. However, resultant maximum tensile forces seem to be unaffectted from reinforcement density. Resultant maximum tensile forces are calculated as $48 \mathrm{kN} / \mathrm{m}, 42 \mathrm{kN} / \mathrm{m}$ and $48 \mathrm{kN} / \mathrm{m}$ for high, medium and low reinforcement density respectively.

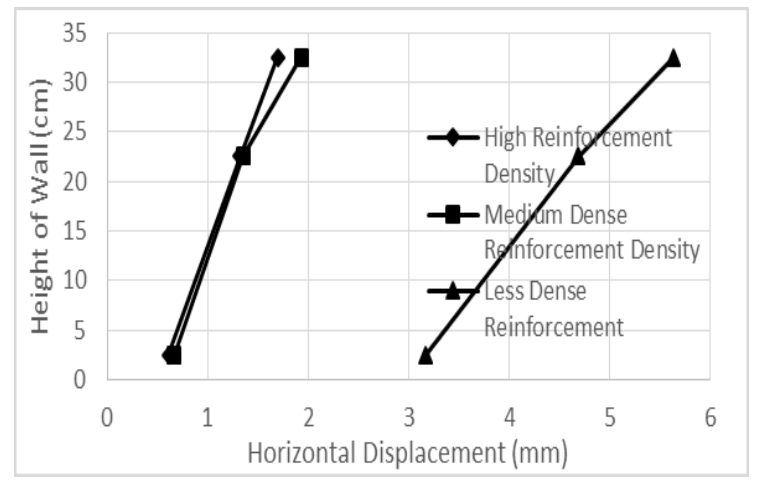

Figure 18. Horizontal displacement of the wall according to reinforcement density

3) Factor of Safety against Slope Stability: Factor of safety against slope stability is investigated according to applied load to reinforced earth wall, reinforcement stiffness, and reinforcement density. Phi-c reduction method is used during analysis which is a caluclation method provided by finite element code, Plaxis. Phi-c reduction method calculates factor of safety by following formula.

$$
\mathrm{F} . \mathrm{S}=\mathrm{c} / \mathrm{c}_{\mathrm{r}}=\tan \phi / \tan \phi_{\mathrm{r}}
$$

Factor of safety against slope stability calculated by above formula by Plaxis is higher in case of clay backfill than sand backfill. However, as load acting over reinforced wall increases factor of safety decreases in case of clay backfill. On the other hand, there are insignificant changes in factor of safety with respect to load in case of sand backfill. Factor of safety is over at least 1.2 for sand and clay backfills under different loads. Change of factor of safety with respect to loads is given on Figure 19.

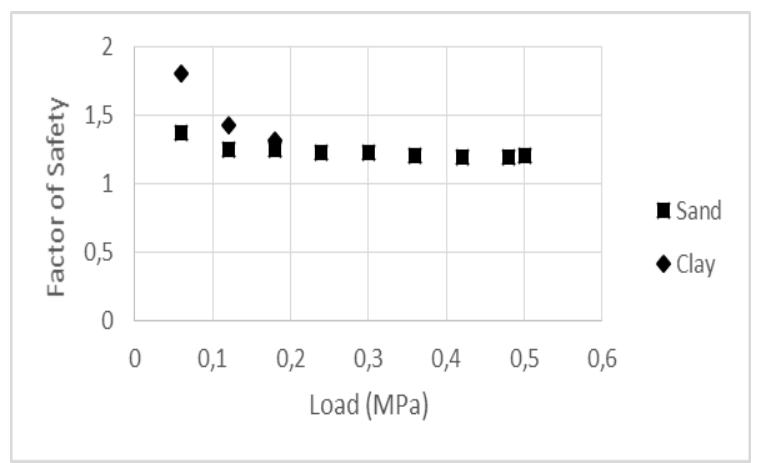

Figure 19. Variation of factor of safety with respect to backfills under different loads 
Calculated factor of safety is 1.04 for low density reinforcement and 1.62 for high density reinforcement. Reinforcement stiffness also has high impact on factor of safety against slope stability. Factor of safety increases from 1.21 to 1.41 as the reinforcement stiffness increases to $10000 \mathrm{kN} / \mathrm{m}$ from $1048 \mathrm{kN} / \mathrm{m}$.

\section{CONCLUSION}

Two reinforced earth walls are constructed at the laboratory which have sand and clay backfill. Those reinforced earth walls are subjected to static testing. Horizontal displacements and settlement of loading plate are measured and recorded. Laboratory test results are used to calibrate finite element model for parametric study.

Breaking points are observed in horizontal displacement - load graphics in case of clay backfills. This behaviour could be attributed to load transfer mechanism from soil to geotextile used in this study. Since load is transferred to geotextile only by friction and clay has considerably lower friction angle than sand, load transfer capacity to geotextile is lower for clay. Therefore, after certain amount of vertical load, clay can not transfer lateral loads to geotextile which caused observation of breaking points for horizontal displacement - load graphics.

Similar loading tests of retaining walls are reported in the literature. Settlement of loading plate is given as $9 \mathrm{~mm}$ by [19] under $0.5 \mathrm{MPa}$. Horizontal wall movement is reported to change between $3 \mathrm{~mm}$ and $8 \mathrm{~mm}$ for different conditions for reinforced earth walls by [20]. Allowable deformation levels of reinforced earth walls are defined in several design codes and collected on [21].According to [21], FHWA defined allowable horizontal wall movement between $0.9 \%$ and $4 \%$, NGC defined between $0.1 \%$ and $0.3 \%$, BS 8006 defined it $0.5 \%$ and PWRC defined it as $3 \%$ with respect to wall movement to wall height ratio. Wall movement to wall height ratio is calculated as $4.4 \%$ and $7.6 \%$ for sand and clay backfill respectively. These values are well above the defined values by standards. That is according to these standards, both of the tested walls failed.

Parametric study is conducted regarding reinforcement stiffness and density. Following conclusions can be given according to the findings of this study.

- Horizontal displacements are lower when sand is used as backfill during construction reinforced earth wall.

- Settlement of loading plate shows different behaviour according to type of backfill.

- $\quad$ Factor of safety against slope stability is higher for reinforced earth wall with clay backfill under same loading condition, however, reinforced earth wall with a clay backfill developes horizontal displacements more easily than reinforced earthwall with sand backfill.

- $\quad$ Finite element model captures the behaviour of reinforced earth wall better in case of sand backfill.

- $\quad$ FHWA design method underestimates tensile loads acting over reinforcements.

- When the reinforcement stiffness is higher, tensile force is higher on geosynthetic,the horizontal deformation and plate settlement is lower. The latter one is more obvious in case of sand backfill. Factor of safety against slope stability is higher when reinforcement stiffness is higher.

- As the reinforcement density increases, factor of safety against slope stability increases, and horizontal displacements of reinforced earth wall decreases.

\section{REFERENCES}

[1] Riccio, M., Ehrlich, M., Dias, D. (2014). Field monitoring and analyses of the response of ablock-faced geogrid wall using fine-grained tropical soils.Geotextiles and Geomembranes, 42, 127- 138. 
[2] Pinho-Lopes, M., Carlos, D. M., Lopes, M. L. (2015). Flume Tests on Fine Soil Reinforced with Geosynthetics: Walls of the Salt Pans (Aveiro Lagoon, Portugal).Int. J. of Geosynth. and Ground Eng, 1(2), $1-12$.

[3] Yang, G., Liu, H., Lv, P., Zhang, B. (2012). Geogrid-reinforced lime-treated cohesivesoil retaining wall: Case study and implications.Geotextiles and Geomembranes, 35, $112-118$.

[4] Yang, G., Ding, J., Zhou, Q., Zhang, B. (2010). Field Behavior of a GeogridReinforced Soil Retaining Wall with a Wrap-Around Facing.Geotechnical Testing Journal, 2010, 33,1-6.

[5] Liu, H., Wang, X., Erxiang Song, E. (2009). Long-term behavior of GRS retaining walls with marginal backfill soils.Geotextiles and Geomembranes, 27, 295 - 307.

[6] Abdelouhab, A., Dias, D., Freitag, N. (2011). Numerical analysis of the behaviour of mechanically stabilized earth walls reinforced with different types of strips. Geotextiles and Geomembranes, 29, $116-$ 129.

[7] Haddad, A., GholamaliShafabakhsh, G. (2008).Failure of segmental retaining walls due to the insufficiency of backfill permeability.Proceedings of the $4^{\text {th }}$ Asian Regional Conference on Geosynthetics, June $17-20$, Shangai, China, $852-856$.

[8] Rowe, R., K., Li, A. L. Insights from case histories: reinforced embankments and retaining walls.

[9] Bourgeois, E., Soyez, L., Kouby A. L. (2011). Experimental and numerical study of the behaviour of a reinforced-earth wall subjected to a local load. Computers and Geotechnics, 38, 515-525.

[10] Mohamed., B., A., S., Yang, K. H., Hung, W., Y. (2014). Finite element analysis of two-tier geosyntheticreinforced soil walls: Comparison involving centrifuge tests and limit equilibrium results. Computers and Geotechnics, 61, $67-84$.

[11] Santos E., C., G., Palmeira, E., M., Bathurst, R., J. (2013). Behaviour of a geogrid reinforced wall built with recycled constructionand demolition waste backfill on a collapsible foundation. Geotextiles and Geomembranes, 39, $9-19$.

[12] Xiao, C., Han, J., Zhang, Z. (2016). Experimental study on performance of geosynthetic-reinforced soil model walls on rigid foundations subjected to static footing loading.Geotextiles and Geomembranes, 44,81 -94 .

[13] Ehrlich, M., Mirmoradi, S., H., Saramago, R., P. (2012). Evaluation of the effect of compaction on the behavior of geosynthetic-reinforced soil walls.Geotextiles and Geomembranes, 34, 108 - 115.

[14] Parka, T., Tan, S., A. (2005). Enhanced performance of reinforced soil walls by the inclusion of short fiber.Geotextiles and Geomembranes, 23, 348-361.

[15] Costa, C., M., L., Zornberg, J., G., Bueno, B., S., Costa, Y., D., J. (2016). Centrifuge evaluation of the time-dependent behavior of geotextile-reinforced soil walls. Geotextiles and Geomembranes, 44(2), 188 - 2007.

[16] Hazra, S., NiharRanjan Patra, N., R. (2008). Performance of Counterfort Walls with Reinforced Granular and Fly Ash Backfills: Experimental Investigation.GeotechGeolEng, 26, 259 - 267.

[17] Ahmadi, H., Bonab, M., H. (2012). Experimental and analytical investigations on bearing capacity of strip footing in reinforced sand backfills and flexible retaining wall.ActaGeotechnica, 7, 357 - 373 .

[18] Reddy, S., B., Krishna, A., M., (2015). Recycled tyre chips mixed with sand as lightweight backfill material in retaining wall applications: an experimental investigation. Int. J. of Geosynth. and Ground Eng, $1-31$. 
[19] Siddique, M. S. A., Tanaka, T., Tatsuoka, F., Tani, K., Morimoto, T., (1999). Numerical simulation of bearing capacity characteristics of strip footing on sand. Soils and Foundations, 39(4), 93 - 109.

[20] Anubhav, S., Basudhar, P., K., (2011). Numerical modelling of surface strip footings resting on doublefaced wrap-around vertical reinforced soil walls. Geosynthetics International 18(1), 21 - 34.

[21] Bathurst, R., J., Miyata, Y., Allen, T., M., (2010). Facing displacements in geosynthetic reinforced soil walls. Earth Retention Conference 3, August 1 - 4, Bellevue, Washington, 442 - 459.

[22] DasBraja. (2010). Principles of Geotechnical Engineering $7^{\text {th }}$ ed. Cengage Learning, Stamford, CT 06902

[23] Federal Highway Administration. (2009). Design and Construction of Mechanically Stabilized Earth Walls and Reinforced Slopes. 